\title{
Entrepreneurial aspirations, motivations, and their drivers
}

\author{
Jolanda Hessels • Marco van Gelderen • \\ Roy Thurik
}

Accepted: 13 July 2008/Published online: 4 September 2008

(C) The Author(s) 2008. This article is published with open access at Springerlink.com

\begin{abstract}
Several drivers of entrepreneurial aspirations and entrepreneurial motivations are investigated using country-level data from the Global Entrepreneurship Monitor (GEM) for the years 2005 and 2006. We estimate a two-equation model explaining aspirations using motivations and socioeconomic variables, and explaining motivations using socioeconomic variables. We find that countries with a higher incidence of increase-wealth-motivated entrepreneurs tend to have a higher prevalence of high-job-growth and export-oriented entrepreneurship and that a country's level of social security relates negatively to the prevalence of innovative, high-job-growth, and export-oriented entrepreneurship. We also find that the increase-wealth motive mediates the relationship between socioeconomic variables and entrepreneurial aspirations.
\end{abstract}

J. Hessels $(\bowtie) \cdot$ R. Thurik

EIM Business and Policy Research,

P.O. Box 7001, 2701 AA Zoetermeer, The Netherlands

e-mail: joh@eim.nl

J. Hessels · R. Thurik

Erasmus University Rotterdam, Rotterdam,

The Netherlands

M. van Gelderen

College of Business, Massey University, Auckland,

New Zealand
Keywords Entrepreneurial motivations ·

Entrepreneurial aspirations .

Global Entrepreneurship Monitor

JEL Classifications $\mathrm{H} 50 \cdot \mathrm{L} 21 \cdot \mathrm{L} 26 \cdot \mathrm{M} 13$

\section{Introduction}

The world of entrepreneurship policy has been shaped by three stylized facts. First, entrepreneurship (business ownership) enhances economic growth (Carree and Thurik 2003; Acs et al. 2004; Audretsch and Keilbach 2004; Acs 2006; van Praag and Versloot 2007). However, entrepreneurship (business ownership) not always stimulates growth (Baumol 1996; Audretsch and Thurik 2001; van Stel and Storey 2004). Van Stel et al. (2005) find that entrepreneurial activity by nascent entrepreneurs and owner/managers of young businesses is positively associated to economic growth only for countries with a high level of per capita income. Second, high-growth firms contribute more to economic growth than small, new, firms in general (Mason 1985; Friar and Meyer 2003; Pages et al. 2003; Wong et al. 2005), while most persons involved in new firm formation have no growth aspiration (Wennekers and Thurik 1999; Henrekson 2005). Third, while there is a plethora of policy measures with an entrepreneurship or small business flavor (Stevenson and Landstrom 2001; 
Landstrom and Stevenson 2005; Audretsch et al. 2007; Acs and Stough 2008), and while high-growth firms are prominent on the agenda of policy-makers (Fischer and Reuber 2003; Smallbone et al. 2002; European Commission 2003), hardly any scientific attention has been devoted to the diversity of entrepreneurs in terms of their aspirations to grow.

This diversity has consequences as well as causes. In terms of consequences, different entrepreneurs contribute differently to growth. Entrepreneurs aspiring to produce novel products, to make their company grow or to indulge in export activities are bound to contribute more to economic growth than their counterparts who have lower levels of aspiration and aim to survive in a corner of the market as a lifestyle entrepreneur (Bellu and Sherman 1995; Kolvereid and Bullvag 1996; Wiklund and Shepherd 2003). In terms of causes, different aspiration levels have different drivers. The present paper is about this second aspect.

One way to explain entrepreneurial aspiration levels is by means of motives (Kolvereid 1992; Amit et al. 2001; Morris et al. 2006; Cassar 2007). Policy goals usually do not correspond with the motives of enterprising individuals. Hardly anybody starts a business in order to achieve innovation, job creation, or economic growth at the national level. Instead, people desire personal profits, or autonomy, amongst others, or are just forced into entrepreneurship because they have no other options (Shane et al. 2003; Locke and Baum 2007). Still, the type of individual entrepreneurial motivation may determine the goals and aspirations for the firm, which in turn may determine macroeconomic outcomes. In either case, it is vital for policy-makers to know what factors within their sphere of influence correlate with individual entrepreneurial motivation, and how entrepreneurial motivations relate to aspirations. These are precisely the two research questions of the present paper.

In this paper we propose a two-equation model where the first one explains aspirators using motivators and socioeconomic variables and the second one explains motivators using socioeconomic variables. This type of two-equation model allows socioeconomic variables to exert both a direct and indirect effect, through motivators, on aspirators. The socioeconomic variables that we take into account are the level of economic development, the rate of economic growth, and the level of social security. Inclusion of the level of social security is based on previous research that suggests that a country's welfare state institutions are likely to affect both the rate of entrepreneurship and its allocation across productive and unproductive activities (Henrekson 2005). However, empirical efforts that explore such links are limited. We try to contribute to the empirical literature by examining whether the level of social security, a factor that has been found to affect the supply of entrepreneurship at the country level in recent empirical contributions (Hessels et al. 2007; Wennekers et al. 2005; Parker and Robson 2004), also affects the supply of aspiring entrepreneurship. The country level is our unit of analysis while 2005 and 2006 Global Entrepreneurship Monitor (GEM) data are used for 36 countries.

The paper is organized as follows. We first discuss literature regarding entrepreneurial motivations and aspirations and develop our hypotheses. In the subsequent sections we elaborate on the main data used, discuss our research methodology, and present the empirical results. Finally, we discuss and interpret our findings and identify policy implications.

\section{Background and hypotheses}

The entrepreneurial decision can be modeled in a stepwise fashion; for instance, Grilo and Thurik (2005) and Grilo and Irigoyen (2006) discriminate between latent and actual entrepreneurship. This setup is loosely inspired by Ajzen's theory of planned behavior (Ajzen 1991). Modeling the entrepreneurial decision as a process is a further development of this approach (Grilo and Thurik 2008; van der Zwan et al. 2008). In the present paper, we discriminate between the aspiration and the motivation stage. In the present section, we will first deal with the drivers of entrepreneurial aspirations (Hessels et al. forthcoming), developing seven hypotheses. Second, we will discuss the drivers of entrepreneurial motivations, developing seven hypotheses. Investigating the drivers of entrepreneurial aspirations we build on an earlier paper which-compared to the present paper-neglects the motivational perspective, emphasizes the role of social security, and uses GEM 2005 data only (Hessels et al. forthcoming). 


\subsection{Drivers of entrepreneurial aspirations}

It is important to understand the role of entrepreneurial motivations when trying to understand entrepreneurial outcomes (Shane et al. 2003; Locke and Baum 2007). There are many individual-level studies on entrepreneurial motivations, defined as the motivation for founding a business, investigating variances across people in motivations. These studies are mostly within-country studies and they come in four types. First, there are studies of reasons or motives to start a firm. Such reasons or motives can be classified as either opportunity or necessity (Reynolds et al. 2001; Acs 2006), a distinction akin to "pull" and "push". These types of studies, being mostly conducted in developed countries where push motives are less prevalent, report mostly pull motives such as autonomy (independence, freedom), income and wealth, challenge, and recognition and status (Kolvereid 1996; Feldman and Bolino 2000; Carter et al. 2003; Wilson et al. 2004). Autonomy or independence is one of the most cited pull factors for starting a business (Shane et al. 1991; Kolvereid 1996; Carter et al. 2003; Van Gelderen and Jansen 2006). However, individuals may also be pushed into entrepreneurship (Thurik et al. 2008). Necessity motives for example occur when (a threat of) unemployment forces people into self-employment. Second, there are cost-benefit types of studies that try to explain the decision to (intent to) start a business (Douglas and Shepherd 2002). In this type of study, material and immaterial risks and gains are brought into some decision function. Third, there are studies of entrepreneurial motivation investigating depth-psychological motives. Examples are studies on need for achievement (nAch) (McClelland 1961) and need for power (nPower) (McClelland 1975). These types of studies suggest that there is a small, but significant, positive relation between nAch and entrepreneurship (Rauch and Frese 2007). nAch and nPower usually do not figure heavily in the first two types of studies, as actual business starters do not often list these motives as conscious reasons to start a business. Fourth, there are multinomial logit-type investigations explaining the odds of being in a certain stage of the entrepreneurial process vis-à-vis not considering selfemployment at all (Grilo and Thurik 2008). Similarly, the drivers of the odds of actually running a business vis-à-vis the nascent stage provide insight in the role of motivations for start-up. Studies of entrepreneurial intentions (Krueger et al. 2000; Van Gelderen et al. 2008a) routinely investigate motivational variables.

The individual-level studies on entrepreneurial motivation have mostly been used to explore differences between entrepreneurs, and whether and how entrepreneurs differ from the population in general or from managers. There is a need for research that considers how entrepreneurial motivations impact entrepreneurial decisions (Shane et al. 2003).

Next to individual-level studies there are betweencountry studies. These studies look at motives on an aggregate level and focus on variance across countries in entrepreneurial motivations. Shane et al. (1991), comparing the UK, Norway, and New Zealand, as well as Baum et al. (1993), comparing Israel and the USA, indeed found that prevalence rates of different motives and needs vary between countries. This type of research has also demonstrated that necessity motives play a major role in developing countries, and also in developed countries, albeit to a lesser extent (Reynolds et al. 2002; Grilo and Thurik 2006; Bhola et al. 2006). Freytag and Thurik (2007) report on the influence of countrylevel variables such as economic freedom, life expectancy, and intensity of health care on the preference for entrepreneurship.

A number of previous studies have related motives to aspirations; for example, Kolvereid (1992) finds that the achievement motive is positively related to growth ambitions. Curiously, financial motives are not included in this study. Davidsson (1989) explains growth willingness based on differences in the expected outcomes of growth. He finds that, if business owners expect increases in financial rewards and in independence, they have more ambitions to grow. Conversely, if they fear a loss of control, or expect that employee well-being will be reduced in the case of growth, their ambitions to grow tend to be limited. Wiklund et al. (2003) also explain growth ambitions from its expected consequences and find that concern for employee well-being is the strongest predictor: if business owners would expect employee well-being to go up in case of growth, their growth ambitions would be large, and vice versa. The authors note that the high importance attached to employee well-being may be specific to Sweden. Cassar (2006) discovers that nascent entrepreneur opportunity costs, measured as household income, education, and 
managerial experience, are a positive influence on growth ambitions. Van Gelderen et al. (2006) in the Dutch Panel Study of Entrepreneurial Dynamics (PSED) study unearth that push motivation is a fail factor for nascent entrepreneurs with high ambitions. Grilo and Irigoyen (2006) and Grilo and Thurik (2005) use the revealed preference for self-employment as an indicator of the entrepreneurial aspiration and establish that perception of lack of financial support has no influence, and that the level of risk tolerance has a positive influence, whereas the perception of administrative complexity has a negative effect on this preference measure. They also show that this measure of entrepreneurial drive in generally lower in European countries than in the USA.

In the present study we are interested in investigating the extent to which entrepreneurial motivations are driving entrepreneurial aspirations. We consider three types of start-up motivations: the independence motive, the increase-wealth motive, and the necessity motive. We take the country level as the unit of analysis. A comprehensive betweencountry study providing entrepreneurial motives and aspirations became available in 2005 when the GEM for the first time distinguished between independence and wealth attainment on the one hand (within the category of pull or opportunity motivation), and necessity entrepreneurship on the other hand. GEM also measures a range of variables with regard to ambitions of innovativeness, job growth, and export. So for the present study we have three dimensions of motivation and three of aspiration. We acknowledge that the motivation data are somewhat limited since there are more motivations to start a business than income/wealth, independence, and necessity. However, for the purpose of cross-national comparison of the relation between entrepreneurial motivations and aspirations, these are the best data available. Note that ideally we would focus our research on the individual level. However, since it takes a lag of several years for GEM microdata to become publicly available for individual countries we have decided to start by focusing on the country level.

We argue that, when trying to explain why some countries have higher prevalence rates of aspiring entrepreneurs than others, it is relevant to consider a country's incidence of various start-up motives. We first consider independence-motivated entrepreneurship. Entrepreneurs for whom autonomy or independence is a dominant motive for becoming self-employed probably have limited growth ambitions for their business. Entrepreneurship is likely to be a vehicle to serve the freedom-related needs of the individual as it enables a lifestyle in which one can decide oneself on goals, methods, and time scheduling (Breaugh 1999). However, autonomy-driven entrepreneurs may still increase diversity in the economy just because they do things in their own way (Van Gelderen et al. 2008a). Autonomy is valued by some for its own sake (van Gelderen and Jansen 2006), and thus is an intrinsic motive. Experimental research shows that intrinsic motivation is related to creativity (Amabile 1996). Previous research at the microlevel suggests that independence is a prime entrepreneurial motive for creating innovative ventures (Corman et al. 1988). On the whole, at the country level we expect that the proportion of independence-motivated entrepreneurs does not relate to the prevalence of growth-oriented entrepreneurship and relates positively to the prevalence of innovation-oriented entrepreneurship.

Furthermore, when people start up a business with the prime motive to increase income this is likely to relate positively to their ambitions for growth and innovation. Both growth and innovation may be instrumental to achieving a higher income. Cassar (2007), focusing on the microlevel and investigating the relationships between financial motives and a range of ambition and outcome variables, indeed found a positive relationship between financial motivations and aspirations. Regression analyses showed growth preference, risk-return preference, intended sales, and intended employment all to be explained by motivations of financial success at the $p<0.001$ level. In a sample of females, Morris et al. (2006) present qualitative as well as quantitative data showing that financial motives positively relate to growth ambitions. Amit et al. (2001) report a group of high-technology high-growth entrepreneurs to be primarily driven by nonfinancial motives. However, their research did not study entrepreneurs motivated by financial rewards. Overall, at the country level we expect that having a higher proportion of increasewealth-motivated entrepreneurs will relate positively to the prevalence of aspiring entrepreneurs.

Generally, necessity-motivated entrepreneurs tend to have lower aspiration levels than opportunitymotivated entrepreneurs (Reynolds et al. 2002). 
Since necessity-motivated entrepreneurs are likely to depend heavily on their firm for daily economic survival this may positively affect the aspirations they have for their firm. However, as necessitymotivated entrepreneurs are more likely to be found in lower-income regions, they are likely to be constrained in their access to human capital, financial capital, technology, and other resources. Consequently, this is likely to inhibit their potential for generating innovations and job growth and for building competitive advantages needed for export. Thus, even though these types of entrepreneurs are often highly dependent on their firm, they lower their expectations for innovation and growth in terms of jobs and export as they expect or acknowledge that such ambitions may be difficult for them to realize. They may also be forced, because of their situation, to act on less promising opportunities (Morris et al. 2006). Therefore, on average we expect a neutral relationship between a country's incidence of necessity-motivated entrepreneurship and entrepreneurial aspirations for innovation and growth.

To summarize, we expect that both the independence motive and the increase-wealth motive are drivers of entrepreneurial aspirations in terms of innovation, and also that the increase-wealth motive is a driver of job growth and export aspirations. This leads to the following hypotheses:

Hypothesis 1 A country's prevalence of entrepreneurs aspiring to innovate is positively related to a country's incidence of independence-motivated entrepreneurs.

Hypothesis 2A A country's prevalence of entrepreneurs aspiring to innovate is positively related to a country's incidence of increase-wealth-motivated entrepreneurs.

Hypothesis 2B A country's prevalence of entrepreneurs aspiring to grow (in terms of jobs) is positively related to a country's incidence of increase-wealthmotivated entrepreneurs.

Hypothesis 2C A country's prevalence of entrepreneurs aspiring to export is positively related to a country's incidence of increase-wealth-motivated entrepreneurs.

We also expect that, when trying to explain a country's prevalence of entrepreneurial aspiration rates, it is relevant to take into account socioeconomic proxies, such as the level of economic development, the rate of economic growth, and the level of social security. The expected impact of economic development is not completely straightforward. On the one hand, in wealthier regions, entrepreneurs have better access to resources, knowledge, and technology, and therefore may be better able to strive for innovation and growth with their firm. On the other hand, in less wealthy regions entrepreneurs are more likely to depend on their firm for survival, which may stimulate them to strive for growth, whereas entrepreneurship is more popular as a vehicle to serve the freedom-related needs of the individual in wealthier regions. Despite these considerations, we still expect a positive relationship between aspirations and the level of wealth, because of the argument that resources, knowledge, and technology are more widely available than in less wealthy regions, which is likely to offer opportunities for innovation and growth for individual entrepreneurs.

Regarding a country's level of growth it can be expected that a higher rate of economic growth will provide entrepreneurial opportunities and therefore we assume entrepreneurial aspirations to be positively related to economic growth (Thurik et al. 2008).

Furthermore, relying on new institutional economics that emphasizes that institutions may both enable and constrain the actions of economic agents (North 1990; Williamson 1998) it can be argued that the supply of entrepreneurship as well as its allocation across productive and unproductive activities is likely to be affected by the institutional setup of societies (Henrekson 2007). In this respect welfare state institutions may be of particular relevance. Henrekson (2005) describes in detail how various welfare state arrangements may create disincentive effects for entrepreneurship and in particular for innovative and growth-oriented entrepreneurship. However, to date empirical efforts on the effects of the welfare state on the supply and types of entrepreneurship are still limited.

One aspect of welfare state institutions that has received some attention in recent empirical research with respect to the supply of entrepreneurship is social security arrangements. From a theoretical perspective social security arrangements, for example, in the case of illness or unemployment, may in 
various ways influence decisions of individuals when choosing between waged employment and selfemployment. A generous social security system may lead to fewer but also to more self-employed. There may be a negative impact on self-employment as generous social security benefits for employees increase the opportunity costs of entrepreneurship. Social security in general may have a positive effect on entrepreneurial activity by creating a safety net in case of business failure. Empirical results suggest that social security negatively affects the level of entrepreneurship, providing support for the argument that social security increases the opportunity costs of entrepreneurship (Hessels et al. 2007; Wennekers et al. 2005; Parker and Robson 2004).

In this paper we extend this empirical literature by examining whether social security also affects the quality of entrepreneurship at the country level. Countries with generous social security and welfare schemes do not emphasize the responsibility of the individual for their own survival, which may hamper ambitions to strive for innovation and growth. Also, higher levels of social security often imply higher wage costs, since employers normally have to pay at least part of the social security contribution for their employees (Hessels et al. 2007). This may further limit entrepreneur's aspirations for growth with their firm, since it may be costly for them to hire employees. Overall, it can be observed that entrepreneurs in countries with a relative lack of social security nets, such as is the case in the UK and the USA, tend to be more growth and innovation oriented than in regions where social security systems are more generous such as Sweden or The Netherlands.

In sum, we propose the following hypotheses regarding the relationship between socioeconomic proxies and entrepreneurial aspirations:

Hypothesis 3 A country's prevalence of entrepreneurs aspiring to innovate/grow (in terms of jobs)/ export is positively related to a country's level of economic development.

Hypothesis 4 A country's prevalence of entrepreneurs aspiring to innovate/grow (in terms of jobs)/ export is positively related to a country's rate of economic growth.

Hypothesis 5 A country's prevalence of entrepreneurs aspiring to innovate/grow (in terms of jobs)/ export is negatively related to a country's level of social security.

\subsection{Drivers of entrepreneurial motivations}

Our second research aim is to investigate the countrylevel correlates of entrepreneurial motivations. Necessity versus opportunity (or push versus pull) entrepreneurship is largely determined by the level of economic development in the long run and the actual state of the economy in the short run (Minniti et al. 2006; Thurik et al. 2008). Necessity entrepreneurship is more common in lower-income countries and decreases with the level of economic development (Wennekers et al. 2005). Gross domestic product (GDP) growth has no significant impact on necessity entrepreneurship and a positive impact on opportunity entrepreneurship (van Stel et al. 2007). However, the impact of these variables may also differ for different types of opportunity entrepreneurship.

When looking specifically at the prevalence of the income/wealth motive versus the independence motive within the entrepreneurial population it is obvious that many individual determinants such as experience, personality, education, and financial position play a role when explaining these motives. The nature of the opportunity will influence entrepreneurial motivation, although there may be a strong reversed causality: an entrepreneurial motivation will influence the process of opportunity recognition. The nature of the environment in terms of hostility, munificence, and dynamism will impact on entrepreneurial motivation.

Country-level determinants have been investigated to a lesser extent. With regard to national culture, some research has related entrepreneurial motivations to Hofstede's dimensions (Hayton et al. 2002). However, as Hayton et al. note, statements of motives tend to be restatements of cultural values, e.g., independence and autonomy reflect individualism. Cultural values are based on individual-level responses, which causes this type of research to tend to fall into the tautology trap. Noorderhaven et al. (2004) and Wennekers et al. (2007) deal with dissatisfaction and uncertainty avoidance, respectively, but jump to the incidence of self-employment instead of its motives in their empirical part.

Another explanation involving culture is offered by Inglehart's work on postmaterialism, applied to 
entrepreneurship by Uhlaner and Thurik (2007). The postmaterialism hypothesis is based in turn on two subhypotheses, that of socialization and that of scarcity. The socialization hypothesis assumes that someone's values reflect to a great extent the prevailing circumstances during his/her formative years. The scarcity hypothesis assumes that someone's priorities reflect his/her socioeconomic circumstances; therefore he/she attaches the greatest value to relatively scarce goods. Thus, level of economic development should be a predictor of whether the population favors nonmaterialistic life goals (such as independence) over materialistic ones (such as income/wealth). On the other hand, the rate of economic growth might increase entrepreneurial opportunities for profits and growth and, therefore, may induce people to favor materialistic start-up goals.

Social security arrangements may be yet another correlate of whether entrepreneurs favor autonomy or wealth/income motives or are necessity motivated. A low level of social benefits means that economic survival of entrepreneurs will depend on the survival of their business, making it likely that these entrepreneurs will be motivated by the income/wealth motive or by the necessity motive. Where levels of social security are high, such as in Western Europe or Scandinavia, entrepreneurship may be very popular as a means for serving the freedom-related needs of the individual.

In sum, we expect that a country's level of economic development and its level of social security are drivers of independence-motivated entrepreneurship. Furthermore, a country's rate of economic growth is expected to positively affect the incidence of increase-wealth-motivated entrepreneurship, whereas its level of economic development and its level of social security are anticipated to hamper the incidence of this motive. Finally, economic development and social security are both predicted to negatively relate to the extent to which entrepreneurs start a firm out of necessity. The following hypotheses reflect our predictions:

Hypothesis 6A A country's incidence of independence-motivated entrepreneurs is positively related to a country's level of economic development.

Hypothesis 6B A country's incidence of independence-motivated entrepreneurs is positively related to a country's level of social security.
Hypothesis 7A A country's incidence of increasewealth-motivated entrepreneurs is negatively related to a country's level of economic development.

Hypothesis 7B A country's incidence of increasewealth-motivated entrepreneurs is positively related to a country's rate of economic growth.

Hypothesis 7C A country's incidence of increasewealth-motivated entrepreneurs is negatively related to a country's level of social security.

Hypothesis 8A A country's incidence of necessitymotivated entrepreneurs is negatively related to a country's level of economic development.

Hypothesis 8B A country's incidence of necessitymotivated entrepreneurs is negatively related to a country's level of social security.

\section{Methodology and data}

In order to test our hypotheses we carry out regression analysis in the framework of a twoequation model. First, we will examine the impact of entrepreneurial motivations and socioeconomic variables on entrepreneurial aspirations, taking into account controls. Next, we will examine empirically what is the influence of socioeconomic variables (while including controls) on entrepreneurial motivations. This setup allows for socioeconomic variables to exert both a direct as well as an indirect effect on entrepreneurial aspirations through motivation. This leads to the following two equations:

$A=f_{1}(M, S, X)$,

$M=f_{2}(S, X)$,

where $A$ represents entrepreneurial aspirations, $M$ represents entrepreneurial motivations, $S$ represents socioeconomic variables, and $X$ represents control variables.

\subsection{Entrepreneurial aspirations}

For measures of entrepreneurial aspirations we use data from the GEM Adult Population Survey 2005 and 2006 on innovativeness, job growth expectations, and export orientations. They relate to the total earlystage entrepreneurial activity (TEA) rate, which is 
defined as the percentage of the adult population (1864 years old) that is either actively involved in starting a new firm (nascent entrepreneur) or that is the owner of manager of a business that is $<42$ months old (young business owner). In order to measure aspirations for innovation and growth GEM asks entrepreneurs and business owners involved in TEA to evaluate the novelty of the technology they use, the newness of their product or service, and about their expectations for growth. One should keep in mind that such an assessment of innovativeness and growth expectations is rather context specific and that what is innovative in one country is not necessarily regarded as innovative in another country (Minniti et al. 2006).

For entrepreneurial aspiration rates in terms of innovativeness we use the following indicators:

- New technology rate. The rate of early-stage entrepreneurs in the adult population indicating making use of technologies that have been available for $<1$ year.

- New product rate. The rate of people involved in TEA as a percentage of the adult population indicating offering a product or service that is new to the market.

- Limited competition rate. The rate of people involved in total early-stage entrepreneurial activity as a percentage of the adult population reporting offering a product or service that is offered by no or only a few other businesses.

Furthermore, next to aspirations related to innovation we also look at aspirations for growth in terms of both job growth and exports. As indicators for entrepreneurial aspiration rates for job growth we use:

- Medium job growth rate. The rate of early-stage entrepreneurs in the adult population that expect to create six or more jobs in the next 5 years.

- High job growth rate. The rate of early-stage entrepreneurs that expect to create 20 or more jobs in 5 years' time.

As indicators for aspiration rates in terms of export orientation we use:

- Export rate. The rate of early-stage entrepreneurs for whom at least $1 \%$ of their customers live outside the country borders.
- Substantial export rate. The rate of early-stage entrepreneurs for whom $26 \%$ or more of their customers live abroad.

\subsection{Entrepreneurial motivations}

Several measures of entrepreneurial motivation are used in the present paper. These measures are taken from the GEM Adult Population Survey 2005 and 2006. Respondents in the GEM Adult Population Survey were first asked to indicate whether they are involved in a start-up to take advantage of a business opportunity or because they have no better choices for work. When they indicate to take advantage of a business opportunity this is considered as opportunity motive, and when they indicate to have no better choices for work they are classified as necessitymotivated entrepreneurs. Next, opportunity-motivated entrepreneurs were asked to indicate the most important motive for pursuing this opportunity, which includes the independence and the increasewealth motives (they could only select one motive). Based on these questions we use the following indicators for the incidence of various entrepreneurial motives expressed as a percentage of TEA:

- Necessity motive. The share of early-stage entrepreneurs that indicate participation in entrepreneurial activity primarily because they have no other options for work.

- Independence motive. The share of early-stage entrepreneurs for whom independence is the main motive for becoming an entrepreneur.

- Increase-wealth motive. The share of early-stage entrepreneurs who indicate that their prime motive for being or becoming an entrepreneur is to increase wealth.

The three motives that we distinguish are mutually exclusive. However, they do not add up to $100 \%$ since people may also have other motives for becoming self-employed such as need for achievement and need for power (see also Sect. 2).

\subsection{Socioeconomic variables}

We include the following socioeconomic variables for indicating the level of economic development, the 
rate of economic growth, and the level of social security at the country level:

- GDP per capita (logarithm). We measure level of economic development by means of GDP per capita. Gross national income per capita is expressed in purchasing power parities per US\$ for 2005. These data are taken from the World Development Indicators database of the World Bank.

- GDP growth. Data on GDP growth for 2005 were taken from the World Economic Outlook Database from the International Monetary Fund (IMF).

- Social security contribution rate. This is the total (employer's and employee's) compulsory social security contribution rate for the year 2004 taken from the World Competitiveness Yearbook 2005 (WCY).

\subsection{Controls}

In addition to the variables presented above we control for a country's age and industry structure. ${ }^{1}$ Previous studies at the microlevel have identified age and industry as important determinants for aspirations in terms of innovation and growth (Lafuente and Salas 1989; Simpson and Kujawa 1974; Westhead 1995; Knight and Cavusgil 1996; Madsen and Servais 1997). Furthermore, we also include a year dummy to capture any time-specific effect of global factors such as aggregate business cycle variations or global exogenous economic shocks.

- \% Population 25-44 years. This variable refers to the percentage of people aged 25-44 years in the total population for the year 2005 and 2006. Data are taken from the US Bureau of the Census.

- Value added in services (\% of GDP). We use data on value added in services from the World Development Indicators database of the World Bank for the year 2005. Value added is the net

\footnotetext{
${ }^{1}$ Because of the small number of observations we are only able to incorporate a limited number of control variables. GDP per capita serves as a catch-all variable encompassing many different aspects of a country's standard of living such as the level of education of its population and a country's technological readiness.
}

output of the sector after adding up all outputs and subtracting intermediate inputs.

- Year dummy 2006. The year dummy takes the value 0 for the year 2005 and the value 1 for the year 2006.

\section{Empirical analysis}

We estimate the equations as presented above using data for 36 countries that have participated in the GEM in 2005 and/or 2006. In total we have 63 observations. The countries that are included in the analysis are Argentina, Australia, Austria, Belgium, Brazil, The Czech Republic, Chile, China, Colombia, Denmark, Finland, France, Germany, Greece, Hungary, Iceland, India, Indonesia, Ireland, Italy, Japan, Malaysia, Mexico, The Netherlands, Norway, Philippines, Russia, Singapore, Slovenia, South Africa, Spain, Sweden, Thailand, Turkey, the UK, and the USA.

Table 1 displays the correlations among the variables that we include in our analysis and also some descriptives (mean and standard deviation). Some of the correlation coefficients among the independent variables are above 0.5 , which indicates that problems of multicollinearity may exist when carrying out regression analysis. For this reason, we tested for multicollinearity in all our regression models using the variance inflation factor (VIF) method. We do not observe VIF above 10 (the highest VIF that we find is 4.7), indicating that multicollinearity is not a concern.

\subsection{Equation 1: investigating the influence of entrepreneurial motivations and socioeconomic variables on entrepreneurial aspirations}

We investigated the influence of entrepreneurial motivations and socioeconomic variables on entrepreneurial aspirations by carrying out regression analyses. Regression results are presented in Table 2. For the increase-wealth motive we find a significant positive relation with the high job growth rate $(p<0.05)$ and on the export rate $(p<0.05)$. We do not find a significant association for the necessity motive and the independence motive with the ambition variables. Thus, hypotheses $2 \mathrm{~B}$ and $2 \mathrm{C}$ receive some support, while the results do not support hypotheses 1 and $2 \mathrm{~A}$. 


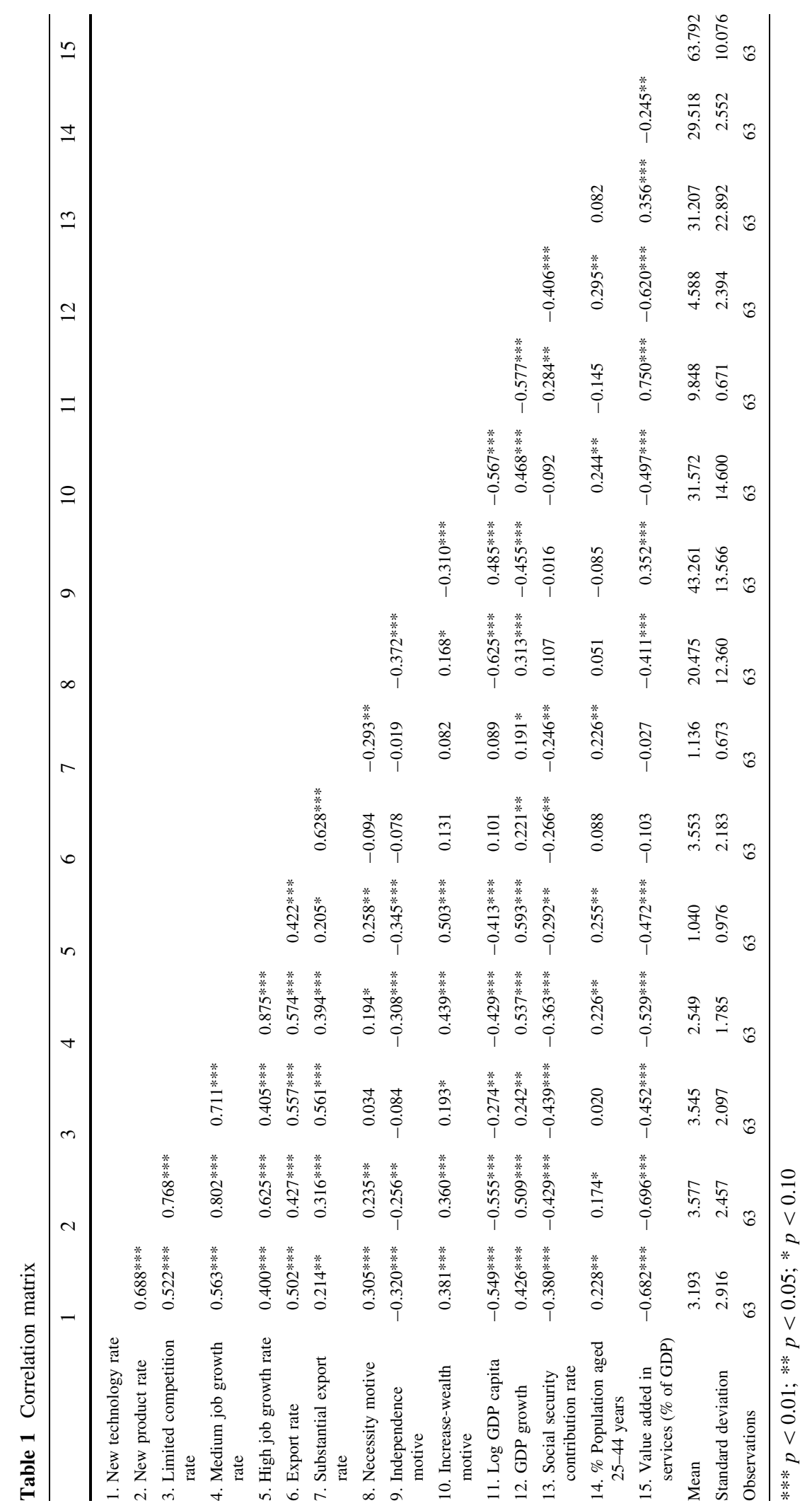




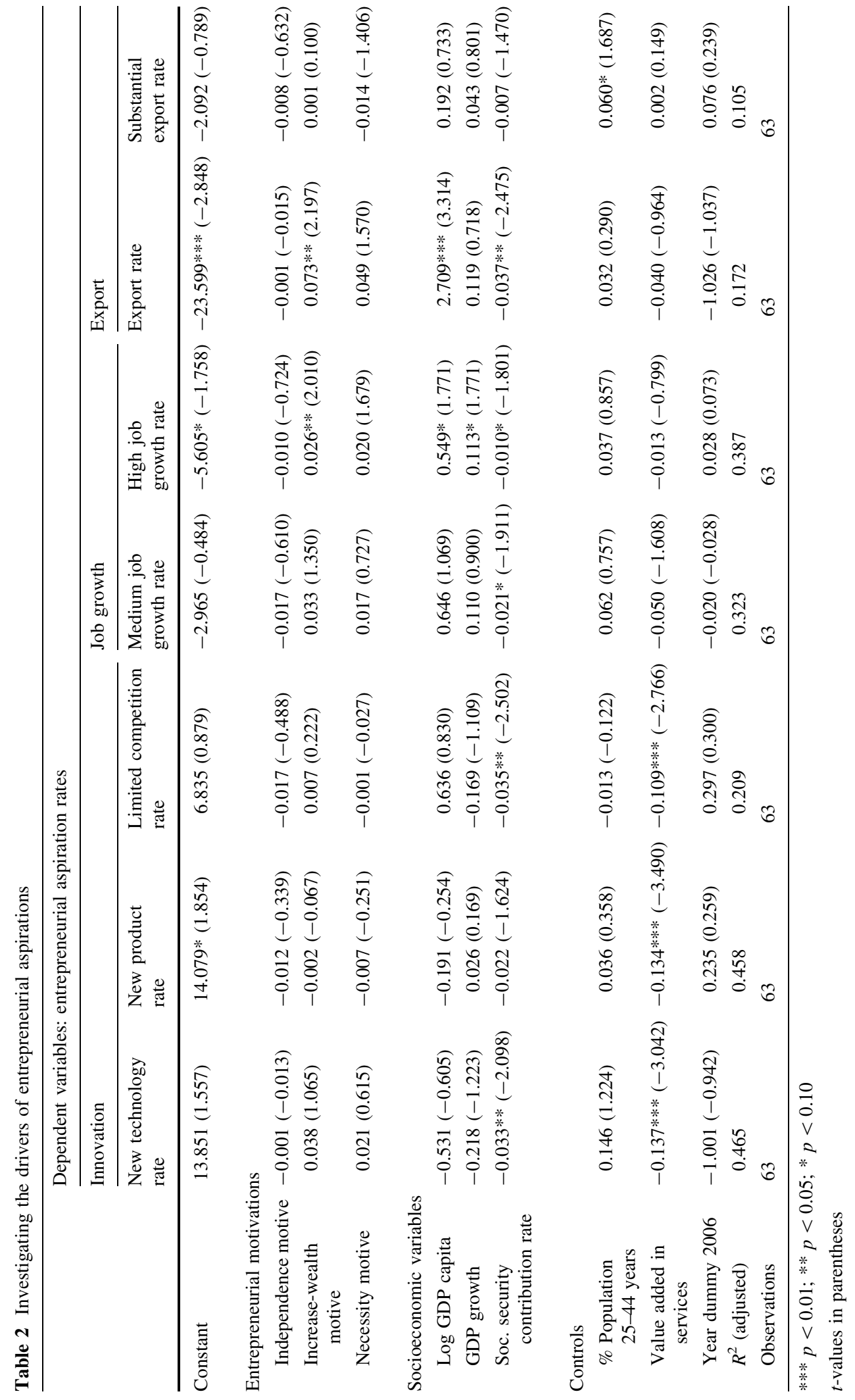


Table 1 further shows that GDP per capita is significant positively related to the high job growth rate and to the export rate, thus we find little support for hypothesis 3. GDP growth displays a significant positive relation with the high job growth rate $(p<0.10)$ and no significant relation with any of the other aspiration variables, indicating that hypothesis 4 receives hardly any support. For the social security contribution rate we find a significant negative impact on most aspiration variables, with the exception of the new product rate and the substantial export rate, meaning that we find some support for hypothesis 5 .

Furthermore, the results indicate that the share of the population that is aged between 25-44 years has a positive impact on the substantial export rate. We do find a significant negative impact for our control variable for a countries sector structure (value added in services) on our aspiration variables that relate to innovation.

4.2 Equation 2: investigating the influence of socioeconomic variables on entrepreneurial motivations

Regression results for Eq. 2 are presented in Table 3. As hypothesized, we find that GDP per capita is negatively related to the necessity motive $(p<0.01)$, negatively to the increase-wealth motive $(p<0.05)$, and positively to the independence motive $(p<0.01)$. These findings provide support for hypotheses $6 \mathrm{~A}, 7 \mathrm{~A}$, and $8 \mathrm{~A}$. For GDP growth we find a significant negative relationship with the independence motive $(p<0.01)$, a significant positive relationship with the increase-wealth motive $(p<0.10)$, and no significant relationship with the necessity motive. Thus, we do find some support for hypothesis 7B. For social security we find a somewhat surprising impact. Social security displays a significant positive relationship with the necessity motive $(p<0.01)$ and a significant negative relationship with the independence motive $(p<0.01)$. Our results do not uphold hypotheses $6 \mathrm{~B}, 7 \mathrm{C}$, and $8 \mathrm{~B}$.

On the basis of these results for Eq. 2 it is possible to identify some indirect effects of the socioeconomic on entrepreneurial aspirations through entrepreneurial motivation. For example, for GDP per capita there is a direct positive impact on high job growth and export orientation and also an indirect negative impact on these variables through the increase-wealth motive. GDP growth has a direct positive impact on high job growth and also an indirect positive impact on the high job growth rate and the export rate through the increase-wealth motive.

\section{Discussion and conclusion}

This paper investigates whether a country's incidence of various entrepreneurial motivations and
Table 3 Investigating the drivers of entrepreneurial motivations
$* * * p<0.01 ; * * p<0.05$;

$* p<0.10$

$t$-values in parentheses

\begin{tabular}{|c|c|c|c|}
\hline & \multicolumn{3}{|c|}{ Dependent variables: entrepreneurial motivations } \\
\hline & $\begin{array}{l}\text { Independence } \\
\text { motive }\end{array}$ & $\begin{array}{l}\text { Increase-wealth } \\
\text { motive }\end{array}$ & $\begin{array}{l}\text { Necessity } \\
\text { motive }\end{array}$ \\
\hline Constant & $-57.244 * *(-2.336)$ & $79.141 * * *(2.691)$ & $155.782 * * *(5.842)$ \\
\hline \multicolumn{4}{|l|}{ Socioeconomic variables } \\
\hline Log GDP capita & $10.674 * * *(4.207)$ & $-7.247 * *(-2.380)$ & $-13.268 * * *(-4.806)$ \\
\hline GDP growth & $-2.326 * * *(-3.688)$ & $1.332 *(1.759)$ & $0.473(0.690)$ \\
\hline $\begin{array}{l}\text { Soc. security } \\
\text { contribution rate }\end{array}$ & $-0.159 * * *(-2.942)$ & $0.084(1.300)$ & $0.185 * * *(3.147)$ \\
\hline \multicolumn{4}{|l|}{ Controls } \\
\hline $\begin{array}{l}\% \text { Population } \\
25-44 \text { years }\end{array}$ & $0.396(0.858)$ & $0.457(0.824)$ & $-0.467(-0.929)$ \\
\hline $\begin{array}{l}\text { Value added in services } \\
\text { (\% of GDP) }\end{array}$ & $-0.142(-0.802)$ & $-0.086(-0.403)$ & $0.036(0.185)$ \\
\hline Year dummy 2006 & $15.052 * * *(6.831)$ & $12.681 * * *(4.795)$ & $-1.929(-0.804)$ \\
\hline$R^{2}$ (adjusted) & 0.608 & 0.512 & 0.440 \\
\hline Observations & 63 & 63 & 63 \\
\hline
\end{tabular}


socioeconomic variables can explain the prevalence of aspiring entrepreneurship, and whether socioeconomic variables can explain a country's incidence of entrepreneurial motivations. Many studies focus on aspects of entrepreneurial motivation in relation to starting or taking over a firm (Shane et al. 2003; Locke and Baum 2007). Nevertheless, little is known about the determinants of various entrepreneurial motives-such as the necessity motive, the independence motive, and the increase-wealth motive-and about how the incidence of these motives affects the aspects of entrepreneurial aspirations such as innovativeness, job growth, and export orientation at the country level.

A substantial part of this paper focuses on investigating the extent to which entrepreneurial motivations are related to entrepreneurial aspirations. The results of our empirical exercise support our prediction that people for whom increasing wealth is the prime motive for becoming self-employed tend to be job growth and export oriented, which suggests that such a strategy is needed for these types of entrepreneurs in order to achieve the financial gains that they desire. However, surprisingly, we find no evidence of a relation between the increase-wealth motive and innovative entrepreneurship. Furthermore, contrary to our expectations, we find no evidence that independence contributes to variety. Possibly independence-motivated entrepreneurs are happy to be able to do the work they want to do and not to have to work for others and that for them a comfortable living is enough of a success.

For policy-makers our results imply that they should be aware that entrepreneurs motivated to start a firm out of necessity or to strive for independence are not likely to have high ambitions for their business and therefore are probably not the ones making a significant contribution to their country's innovation, employment creation, and economic growth. This is somewhat of a challenge since in most countries, in particular the richer ones, independence is the most popular start-up motive of the three motives that we take into account in our study. Given the fact that the majority of entrepreneurs in higher-income countries start their own firm out of independence, and given the absence of a relationship between the independence motive and aspiration rates, the results of this study also suggest that it is rewarding for policy-makers to devote attention to the enhancement of aspiration levels among independence-motivated entrepreneurs. In many countries entrepreneurship policies are already shifting their focus from seeking to increase the quantity of entrepreneurs to improving the quality of entrepreneurship, which is reflected in the policy focus on high-growth entrepreneurship (Fischer and Reuber 2003; Smallbone et al. 2002; European Commission 2003). Furthermore, our results further support that policy-makers should have an interest in discouraging necessity-motivated entrepreneurship, since this type of entrepreneurship is not likely to contribute to innovation, job growth, and export.

Furthermore, our results suggest that promoting a higher prevalence of the increase-wealth motive in the population of entrepreneurs seems to be a somewhat advantageous avenue when aiming to support a higher rate of ambitious entrepreneurship. The promotion of increase-wealth-motivated entrepreneurship will be challenging for higher-income countries since the incidence of increase-wealth-motivated entrepreneurs relates negatively to the level of economic development. Therefore, a country's level of economic development (despite its direct positive relationship with high-growth and export-oriented entrepreneurship) even has an indirect negative impact on growthoriented entrepreneurship through the increase-wealth motive. Countries with higher rates of economic growth tend to have higher proportions of increasewealth-motivated entrepreneurs, and consequently economic growth rates also have an indirect positive effect on high job growth and export aspirations through their impact on the increase-wealth motive. Future research should seek to explore the various ways in which policy-makers can stimulate people to start their own businesses with the aim to pursue material gains. Possibly, tax laws and a reduction of compliance costs and red tape are integral elements of such material gain policies.

Another aspect that receives attention in this paper, since it may affect both a country's rate of aspiring entrepreneurship as well as its incidence of entrepreneurial motivations, is the level of social security. Previous empirical studies have explored the relationship between social security arrangements and the supply of entrepreneurship at the country level (Hessels et al. 2007; Wennekers et al. 2005; Parker and Robson 2004). These studies tend to find support for a negative relationship between social security and entrepreneurship. The results of this 
paper illustrate that social security also displays a negative association with the supply of ambitious entrepreneurship. More specifically, we find a negative impact of the social security contribution rate on most ambition variables (with the exception of the rate of early-stages entrepreneurs that introduce new products/services and that have a substantial export orientation), indicating that when social security systems are more generous start-ups tend to be less oriented towards innovation and growth in terms of jobs and exports. Overall, to better exploit entrepreneurship as a potential source for innovation, employment creation, and growth, policy-makers face a challenge of designing social security systems in such a way that they do provide sufficient income security combined with incentives for innovative and growth-oriented behavior. One suggestion is to provide a discount on the employer contribution to entrepreneurs of aspiring firms if they meet certain targets related to innovation, job growth or export. Given the complexity and political sensitivity of such policies, we leave it to future research to explore in more detail this type of policy options.

With respect to the relationship between social security and entrepreneurial motivation the results are somewhat different than we expected. In particular, we find a significant positive relationship between social security and the incidence of the necessity motive (whereas we hypothesized a negative relationship), no relationship between social security and the increase-wealth motive (while we hypothesized a negative relationship), and a significant negative relationship between social security and the independence motive (whereas we hypothesized a positive relationship). An explanation for the positive relationship between social security and the necessity motive may be that a high level of social security reflects a high number of beneficiaries within a country (Hessels et al. 2007), which may indicate that alternative job opportunities are not widely available and may result in a higher share of necessitymotivated entrepreneurs. An explanation for the negative relationship between social security and the independence motive is that, when levels of social security are higher, this may reveal that there is less emphasis on individual responsibility within society, and as a result independence entrepreneurship, which entails taking responsibility for oneself (Shane et al. 2003), is less common.
The empirical part of this study has a number of limitations, such as the small sample size and the cross-sectional nature of the data. Furthermore, we are able to take into account only a limited number of motives currently measured as part of the GEM project. Also, whereas we distinguish between various prime motives for becoming self-employed, in reality individuals may be motivated by a combination of both intrinsic as well as extrinsic factors (Kuratko et al. 1997). In addition, entrepreneurial motives may change over time (Littunen 2000). For example, individuals who started their firm out of independence motives, may over time, as their firm becomes successful, become motivated by achieving financial gains. Future research should seek to take into account such dynamic aspects. Furthermore, in this paper we look at only one aspect of a country's institutional setup (i.e., social security arrangements) and future empirical research should include other institutional elements when investigating the factors that may encourage or discourage various types of ambitious entrepreneurial activity, such as taxation and labor market regulation systems (Henrekson 2007) or education (Levie and Autio 2008). It would also be desirable to use indicators for the social security position of entrepreneurs (relative to that of employees), which is currently not possible due to a lack of data (Hessels et al. 2007). Although a positive relationship can be expected between aspiration levels and outcomes, the current paper does not address such relationships. Future research, for example, could seek to provide more insight into whether and how entrepreneurial aspirations contribute to national economic development (Acs and Amorós 2008; Acs et al. 2008). Despite these limitations, the identified relationships between the type of individual-level motivation and country-level variables on the one hand and firm-level aspirations on the other hand show the potential for motivation- and institution-based policies for an entrepreneurial economy.

Acknowledgement An earlier version of this paper was presented at the 2006 Babson College Entrepreneurship Research Conference. The paper has been written in the framework of the research program SCALES carried out by EIM Business and Policy Research and financed by the Dutch Ministry of Economic Affairs.

Open Access This article is distributed under the terms of the Creative Commons Attribution Noncommercial License which permits any noncommercial use, distribution, and reproduction 
in any medium, provided the original author(s) and source are credited.

\section{References}

Acs, Z. J. (2006). How is entrepreneurship good for economic growth? Innovations, 1(1), 97-107.

Acs, Z. J., \& Amorós, J. E. (2008). Entrepreneurship and competitiveness dynamics in latin America. Small Business Economics, 31(3). doi:10.1007/s11187-008-9133-y.

Acs, Z. J., Audretsch, D. B., Braunerhjelm, P., \& Carlsson, B. (2004). The missing link: the knowledge filter and entrepreneurship in endogenous growth. Discussion Paper, 4783. London: Center for Economic Policy Research.

Acs, Z. J., Desai, S., \& Hessels, J. (2008). Entrepreneurship, economic development and public policy. Small Business Economics, 31(3). doi:10.1007/s11187-008-9135-9.

Acs, Z. J., \& Stough, R. (2008). Public policy in an entrepreneurial economy. New York: Springer.

Ajzen, I. (1991). The theory of planned behaviour. Organizational Behaviour and Human Decision Processes, 50(2), 179-211.

Amabile, T. (1996). Creativity in context. Boulder, CO: Westview.

Amit, R., MacCrimmon, K. R., Zietsma, C., \& Oesch, J. M. (2001). Does money matter: Wealth attainment as the motive for initiating growth-oriented technology ventures. Journal of Business Venturing, 16(2), 119-143.

Audretsch, D. B., Grilo, I., \& Thurik, A. R. (2007). Explaining entrepreneurship and the role of policy: A framework. In D. B. Audretsch, I. Grilo, \& A. R. Thurik (Eds.), The handbook of research on entrepreneurship policy (pp. 1-17). Cheltenham, UK and Northampton, MA, USA: Edward Elgar.

Audretsch, D. B., \& Keilbach, M. (2004). Entrepreneurship capital and economic performance. Regional Studies, 38(8), 949-959.

Audretsch, D. B., \& Thurik, A. R. (2001). What's new about the new economy? From the managed to the entrepreneurial economy. Industrial and Corporate Change, 10(1), 267-315.

Baum, J. R., Olian, J. D., Erez, M., Schnell, E. R., Smith, K. G., Sims, H. P., et al. (1993). Nationality and work role interactions: A cultural contrast of Israeli and U.S. entrepreneurs' versus managers' needs. Journal of Business Venturing, 8(4), 449-512.

Baumol, W. J. (1996). Entrepreneurship: Productive, unproductive, and destructive. Journal of Business Venturing, 11(1), 3-22.

Bellu, R. R., \& Sherman, H. (1995). Predicting business success from task motivation and attributional style: A longitudinal study. Entrepreneurship and Regional Development, 7, 349-363.

Bhola, R., Verheul, I., Grilo, I., \& Thurik, A. R. (2006). Explaining engagement levels of opportunity and necessity entrepreneurs. Research report H200610. Zoetermeer: EIM Business and Policy Research.

Breaugh, J. A. (1999). Further investigation of the work autonomy scales: Two studies. Journal of Business and Psychology, 13(3), 357-373.
Carree, M. A., \& Thurik, A. R. (2003). The impact of entrepreneurship on economic growth. In D. B. Audretsch \& Z. J. Acs (Eds.), Handbook of entrepreneurship research (pp. 437-471). Boston/Dordrecht: Kluwer Academic.

Carter, N. M., Gartner, W. B., Shaver, K. G., \& Gatewood, E. J. (2003). The career reasons of nascent entrepreneurs. Journal of Business Venturing, 18(1), 13-39.

Cassar, G. (2006). Entrepreneur opportunity costs and intended venture growth. Journal of Business Venturing, 21(5), 610-632.

Cassar, G. (2007). Money, money, money? A longitudinal investigation of entrepreneur career reasons, growth preferences and achieved growth. Entrepreneurship and Regional Development, 19(1), 89-107.

Corman, J., Perles, B., \& Vancini, P. (1988). Motivational factors influencing high-technology entrepreneurship. Journal of Small Business Management, 26(1), 36-42.

Davidsson, P. (1989). Entrepreneurship — and after? A study of growth willingness in small firms. Journal of Business Venturing, 4(3), 211-226.

Douglas, E. J., \& Shepherd, D. A. (2002). Self-employment as a career choice: Attitudes, entrepreneurial intentions, and utility maximization. Entrepreneurship Theory \& Practice, 26(3), 81-90.

European Commission. (2003). Green Paper Entrepreneurship in Europe. Retrieved 20 November 2007, from http://europa. eu.int/comm/enterprise/entrepreneurship/green_paper/

Feldman, D. C., \& Bolino, M. C. (2000). Career patterns of the self-employed: Career motivations and career outcomes. Journal of Small Business Management, 38(1), 53-67.

Fischer, E., \& Reuber, A. R. (2003). Support for rapid-growth firms: A comparison of the views of founders, government policymakers, and private sector resource providers. Journal of Small Business Management, 41, 346-365.

Freytag, A., \& Thurik, A. R. (2007). Entrepreneurship and its determinants in a cross-country setting. Journal of Evolutionary Economics, 17(2), 117-131.

Friar, J., \& Meyer, M. (2003). Entrepreneurship and start-ups in the Boston region: Factors differentiating high-growth ventures from micro-ventures. Small Business Economics, $21,145-152$.

Grilo, I., \& Irigoyen, J. (2006). Entrepreneurship in the EU: To wish and not to be. Small Business Economics, 26(4), 305-318.

Grilo, I., \& Thurik, A. R. (2005). Latent and actual entrepreneurship in Europe and the US: Some re-cent developments. International Entrepreneurship and Management Journal, 1(4), 441-459.

Grilo, I., \& Thurik, A. R. (2006). Entrepreneurship in the old and new Europe. In E. Santarelli (Ed.), Entrepreneurship, growth, and innovation: The dynamics of firms and industries: International studies in entrepreneurship (pp. 75-103). Berlin: Springer Science.

Grilo, I., \& Thurik, A. R. (2008). Determinants of entrepreneurial engagement levels in Europe and the US. Industrial and Corporate Change, forthcoming.

Hayton, J. C., George, G., \& Zahra, S. A. (2002). National culture and entrepreneurship: A review of behavioral research. Entrepreneurship Theory \& Practice, 26(4), 33-52. 
Henrekson, M. (2005). Entrepreneurship: A weak link in the welfare state? Industrial and Corporate Change, 14(3), 437-467.

Henrekson, M. (2007). Entrepreneurship and institutions. Comparative Labour Law \& Policy Journal, 28(4), 717-742.

Hessels, J., van Gelderen, M., \& Thurik, R. (2008). Drivers of entrepreneurial aspirations at the country level: the role of start-up motivations and social security. International Entrepreneurship and Management Journal, forthcoming

Hessels, J., van Stel, A., Brouwer, P., \& Wennekers, S. (2007). Social security arrangements and early-stage entrepreneurial activity. Comparative Labour Law \& Policy Journal, 28(4), 743-774.

Knight, G. A., \& Cavusgil, S. T. (1996). The born global firm: A challenge to traditional internationalization theory. In S. T. Cavusgil \& T. K. Madsen (Eds.), Export internationalizing research-enrichment and challenges (Advances in International Marketing series, Vol. 8) (pp. 11-26). New York: JAI.

Kolvereid, L. (1992). Growth aspirations among Norwegian entrepreneurs. Journal of Business Venturing, 7(3), 209-222.

Kolvereid, L. (1996). Organizational employment versus selfemployment: Reasons for career choice intentions. Entrepreneurship Theory and Practice, 20(3), 23-31.

Kolvereid, L., \& Bullvag, E. (1996). Growth intentions and actual growth: The impact of entrepreneurial choice. Journal of Enterprising Culture, 4(1), 1-17.

Krueger, N. F., Jr., Reilly, M. D., \& Carsrud, A. L. (2000). Competing models of entrepreneurial intentions. Journal of Business Venturing, 15, 411-432.

Kuratko, D. F., Hornsby, J. S., \& Naffziger, D. W. (1997). An examination of owner's goals in sustaining entrepreneurship. Journal of Small Business Management, 35(1), 24-33.

Lafuente, A., \& Salas, V. (1989). Types of entrepreneurs and firms: The case of new Spanish firms. Strategic Management Journal, 10, 17-30.

Landstrom, A., \& Stevenson, L. A. (2005). Entrepreneurship policy. New York: Springer.

Levie, J., \& Autio, E. (2008). A theoretical grounding and test of the GEM model. Small Business Economics, 31(3). doi: 10.1007/s11187-008-9136-8.

Littunen, H. (2000). Entrepreneurship and the characteristic of the entrepreneurial personality. International Journal of Entrepreneurial Behaviour and Research, 6(6), 295-309.

Locke, E. A., \& Baum, J. R. (2007). Entrepreneurial motivation. In J. R. Baum, M. Frese, \& R. A. Baron (Eds.), The psychology of entrepreneurship (pp. 93-112). Mahwah, NJ: Erlbaum.

Madsen, T. K., \& Servais, P. (1997). The internationalization of born globals: An evolutionary process. International Business Review, 6(6), 561-583.

Mason, C. M. (1985). The geography of 'successful' small firms in the United Kingdom. Environment and Planning A, 17, 1499-1513.

McClelland, D. C. (1961). The achieving society. Princeton: Van Nostrand.

McClelland, D. C. (1975). Power: The inner experience. New York: Irvington.
Minniti, M., Bygrave, W., \& Autio, E. (2006). Global Entrepreneurship Monitor-2005 Executive Report. Wellesley, MA/London: Babson College and London Business School.

Morris, M. H., Miyasaki, N. N., Watters, C. E., \& Coombes, S. M. (2006). The dilemma of growth: Understanding venture size choices of women entrepreneurs. Journal of Small Business Management, 44(2), 221-244.

Noorderhaven, N., Thurik, A. R., Wennekers, A. R. M., \& van Stel, A. J. (2004). The role of dissatisfaction and per capita income in explaining self-employment across 15 European countries. Entrepreneurship Theory and Practice, 28(5), 447-466.

North, D. (1990). Institutions, institutional change and economic performance. Cambridge: Cambridge University Press.

Pages, E. R., Freedman, D., \& Von Bargen, P. (2003). Entrepreneurship as a state and local economic development strategy. In Hart, D. (Ed.), Entrepreneurship Policy (pp. 240-259). Cambridge: Cambridge University Press.

Parker, S. C., \& Robson, M. T. (2004). Explaining international variations in entrepreneurship: Evidence from a panel of OECD countries. Southern Economic Journal, 71(2), 287-301.

Rauch, A., \& Frese, M. (2007). Born to be an entrepreneur? Revisiting the personality approach to entrepreneurship. In J. R. Baum, M. Frese, \& R. A. Baron (Eds.), The psychology of entrepreneurship (pp. 41-66). Mahwah, NJ: Erlbaum.

Reynolds, P. D., Bygrave, W. D., Autio, E., Cox, L., \& Hay, M. (2002). Global Entrepreneurship Monitor: 2002 Executive Report. Kansas City, MO: Kauffman Center for Entrepreneurial Leadership.

Reynolds, P. D., Camp, S. M., Bygrave, W. D., Autio, E., \& Hay, M. (2001). Global Entrepreneurship Monitor: 2001 Executive Report. Kansas City, MO: Kauffman Center for Entrepreneurial Leadership.

Shane, S., Kolvereid, L., \& Westhead, P. (1991). An exploratory examination of the reasons leading to new firm formation across country and gender. Journal of Business Venturing, 6(6), 431-446.

Shane, S., Locke, E., \& Collins, C. J. (2003). Entrepreneurial motivation. Human Resource Management Review, 13(2), 257-280.

Simpson, C. L., \& Kujawa, D. (1974). The export decision process: An empirical inquiry. Journal of International Business Studies, 5(1), 107-117.

Smallbone, D., Baldock, R., \& Burgess, S. (2002). Targeted support for high-growth start-ups: Some policy issues. Environment and Planning C, 20(2), 195-209.

Stevenson, L. A., \& Landstrom, A. (2001, June). Entrepreneurship policy for the future: best practice components. Keynote speech for the ICSB Conference, Taipei

Thurik, A. R., Carree, M. A., van Stel A. J., \& Audretsch, D. B. (2008). Does self-employment reduce unemployment? Journal of Business Venturing, forthcoming

Uhlaner, L. M., \& Thurik, R. (2007). Post materialism influencing total entrepreneurial activity across nations. Journal of Evolutionary Economics, 17(2), 161-185.

Van Gelderen, M. W., Brand, M., van Praag, M., Bodewes, W., Poutsma, E., \& van Gils, A. (2008a). Explaining 
entrepreneurial intentions by means of the theory of planned behaviour. Career Development International, forthcoming

Van Gelderen, M. W., \& Jansen, P. G. W. (2006). Autonomy as a startup motive. Journal of Small Business and Enterprise Development, 13(1), 23-32.

Van Gelderen, M. W., Sayers, J., \& Keen, C. (2008b). Homebased Internet businesses as drivers of variety. Journal of Small Business and Enterprise Development, 15(1), 162-177.

Van Gelderen, M. W., Thurik, A. R., \& Bosma, N. (2006). Success and risk factors in the pre-startup phase. Small Business Economics, 26(4), 319-335.

Van Praag, C. M., \& Versloot, P. H. (2007). What is the value of entrepreneurship? A review of recent research. Small Business Economics, 29(4), 351-382.

Van Stel, A. J., Carree, M., \& Thurik, A. R. (2005). The effect of entrepreneurial activity on national economic growth. Small Business Economics, 24(3), 311-321.

Van Stel, A. J., \& Storey, D. J. (2004). The link between firm births and job creation: Is there a upas tree effect? Regional Studies, 38(8), 893-909.

Van Stel, A. J., Storey, D. J., \& Thurik, A. R. (2007). The effect of business regulations on nascent and young business entrepreneurship. Small Business Economics, 28(2-3), 171-186.

Wennekers, S., \& Thurik, R. (1999). Linking entrepreneurship and economic growth. Small Business Economics, 13(1), 27-55.

Wennekers, S., van Stel, A., Thurik, R., \& Reynolds, P. (2005). Nascent entrepreneurship and the level of economic development. Small Business Economics, 24(3), 293-309.
Wennekers, S., Thurik, R., van Stel, A., \& Noorderhaven, N. (2007). Uncertainty avoidance and the rate of business ownership across 21 OECD countries, 1976-2004. Journal of Evolutionary Economics, 17(2), 133-160.

Westhead, P. (1995). Exporting and non-exporting small firms in Great Britain. International Journal of Entrepreneurial Behaviour \& Research, 1(2), 6-36.

Wiklund, J., Davidsson, P., \& Delmar, F. (2003). What do they think and feel about growth? An expectancy-value approach to small business managers' attitudes toward growth. Entrepreneurship Theory \& Practice, 27(3), 247-270.

Wiklund, J., \& Shepherd, D. (2003). Aspiring for, and achieving growth: The moderating role of resources and opportunities. Journal of Management Studies, 40(8), 1919-1941.

Wilson, F., Marlino, D., \& Kickul, J. (2004). Our entrepreneurial future: Examining the diverse attitudes and motivations of teens across gender and ethnic identity. Journal of Developmental Entrepreneurship, 9(3), 177-197.

Williamson, O. E. (1998). The institutions of governance. The American Economic Review, 88(2), 75-79.

Wong, B., Ho Y., \& Autio, E. (2005). Entrepreneurship, innovation and economic growth: Evidence from GEM data. Small Business Economics, 24(3), 335-350.

Zwan, P., van der Thurik, A. R., \& Grilo, I. (2008). The entrepreneurial ladder and its determinants. Applied Economics, forthcoming 